\title{
BARRIERS TO INSTITUTIONAL ADOPTION OF NEW PRODUCTS INNOVATION: A CASE OF PRECOOKED BEANS AMONG SCHOOLS IN RWANDA
}

\author{
Alice Mukamugema ${ }^{1 凶}$, Patience Mlongo Mshenga $^{1}$, Abucheli Eliud Birachi ${ }^{2}$ \\ ${ }^{1}$ Egerton University, Kenya \\ ${ }^{2}$ International Center for Tropical Agriculture (CIAT), Rwanda
}

\begin{abstract}
The concept of precooked beans was introduced in Rwanda in 2009, to counteract the disadvantage of too much energy and time consumption associated with dry beans preparation. However, their adoption has been dismal and little is known on the possible causes of this. Therefore, the purpose of this paper is to identify constraints impeding the adoption of precooked beans among secondary boarding schools in Rwanda. A multistage sampling procedure was used to interview 64 caterers of secondary boarding schools. Descriptive statistics were used to analyze constraints hindering the adoption of precooked beans among schools. Also, logistic regression was used to analyze factors influencing the willingness to adopt precooked beans in schools. The results showed 7 major constraints encountered by secondary boarding schools in adopting precooked beans and 5 factors statistically influencing the willingness of schools to adopt precooked beans. The study concluded that the lack of sufficient information, higher price, unavailability, distrust in sustainability claims, lower nutritional value, inconvenient packaging and inadequate storage are the major barriers to adoption of precooked beans in schools. Therefore, this study recommends producers of precooked beans to consider the abovementioned barriers in setting their marketing strategy to enhance the consumption of precooked beans among schools.
\end{abstract}

Keywords: precooked beans, adoption, secondary boarding schools, barriers, new products innovation

\section{INTRODUCTION}

Pulses or legumes are among the most extensively consumed foods globally and have been consumed for over 10,000 years (Mudryj et al., 2014). They are important crops both nutritionally and environmentally. Pulses are potential crops in addressing global food security since they are an affordable source of protein and several minerals (FAO, 2016). Besides, pulses contribute markedly to climate change mitigation. This is, by fixing atmospheric nitrogen in soils, they contribute to fertilizer use reduction, lowering greenhouse gas emission in agricultural production (Singh et al., 2016). Pulses include dry beans, lentils, soybeans and peas.

Dry beans are a good and affordable source of protein, fiber, carbohydrates, vitamins and essential minerals, including manganese, potassium, phosphorus and magnesium (Akibode and Maredia, 2011). Moreover, they possess several health benefits, including reducing cardiovascular, cancer and diabetic risks (Winham et al., 2016). Therefore, dry beans are markedly important particularly in diets of low-income households worldwide due to their nutritious nature. In Rwanda, dry beans are an important staple food and the primary source of protein for about $90 \%$ of households (FAOSTAT, 2012). However, despite these advantages, dry beans are a slowcooking food that require a lot of time (at least 3 hours)

\footnotetext{
$\bowtie$ Alice Mukamugema, Msc, Department of Agricultural Economics and Agri-Business Management, Egerton University, George Morara Rd, Nakuru, Kenya, e-mail: alicemugema10@gmail.com, https://orcid.org/0000-0003-2861-9246
} 
and fuel to be ready for consumption (Sawa, 2016). This makes them an indirect source of deforestation and air pollution which, in turn, lead to environmental degradation, climate change as well as poor health. To counteract this disadvantage, the concept of precooked beans was introduced in Rwanda in 2009.

Precooked beans are processed beans which require to be reheated for less than 15 minutes before consumption (Sawa, 2016). They are processed using electricity, and as they are cooked in bulk, with energy-efficient facilities, low energy is used to produce them. Besides, their preparation requires small amounts of fuel, time and water (Farmfresh, 2017). This implies that their adoption can save considerable fuel, labor and water resources otherwise used to cook dry beans, as well as the costs involved in acquiring them. Therefore, their adoption can be environmentally and economically profitable (Aseete et al., 2018). However, their adoption rates are still low, particularly in institutions such as schools and hospitals.

The adoption of new products innovation is usually constrained by several factors as it has been proven by several studies. According to Van Akkeren and Cavaye (1999), lack of information limits consumers' adoption of a new product since they would not be aware of benefits derived from such innovations as compared to existing solutions. Another study done by Jasiulewicz and Lemanowicz (2016) found that due to consumer rationality, higher prices are a potential barrier to the adoption of new food products innovation. They also found inconvenient packaging, lack of trust in the sustainability claims of new products, and lack of nutritional values, healthiness and taste in the new food products innovation to be the factors limiting their adoption. Further, Aggarwal et al. (1998) found that as consumers are likely to buy easily available products, limited availability of a new product would limit its adoption.

Several studies have been done on constraints impeding individual consumers' adoption of new innovative products. However, empirical studies on the constraints limiting organizational consumers' adoption of new product are scarce. Moreover, factors constraining the adoption of precooked beans among schools in Rwanda remain unknown in empirical literature. Therefore, this study was conducted to identify constraints impeding the adoption of precooked beans among schools in Rwan$\mathrm{da}$, with the aim of contributing towards considerable reduction of deforestation through increased adoption rate of precooked beans among schools in Rwanda.

\section{MATERIAL AND METHODS}

\section{Study area}

The study was conducted in the Republic of Rwanda located in Eastern Africa. The capital city, Kigali, is situated approximate to the center of the country. Rwanda is bordered by Burundi to the South, Uganda to the North, Tanzania to the East and Democratic Republic of the Congo to the West. It is located at latitudes between $1^{\circ} 02^{\prime} 40^{\prime \prime}$ and $2^{\circ} 50^{\prime} 16^{\prime \prime}$ south and longitudes between $28^{\circ} 51^{\prime} 29^{\prime \prime}$ ' and 30 $53^{\prime}$ '56" east (Sirven et al., 1974). The area of Rwanda is estimated at $26,338 \mathrm{~km}^{2}$ with a population of 11,917,508 in 2016 (World Bank, 2018). Further, Rwanda is the most densely populated in East African region (NISR, 2014). The country is divided into 4 provinces, namely: Northern, Southern, Eastern and Western provinces, and Kigali city. These provinces are divided into 30 districts. The study was carried out specifically in the 6 districts of central Rwanda, namely: Gasabo, Kicukiro, Nyarugenge, Bugesera, Kamonyi and Muhanga.

\section{Data and sampling procedure}

Cross-sectional primary data was obtained through a survey in secondary boarding schools conducted in July 2018. A structured questionnaire was used as a tool for data collection and it was administered through faceto-face interviews with caterers of those schools.

A multistage sampling technique was used to select the respondents. First, 3 districts of Kigali city and 3 districts in the neighborhood of Kigali, where the concept of precooked beans started in schools, were purposively selected. Those districts are Gasabo, Kicukiro, Nyarugenge, Bugesera, Kamonyi and Rwamagana. In the second stage, secondary boarding schools in the 6 districts were divided into public and private schools. Then, a stratified random sampling was used to get the desired sample with computed proportions. A sample of $64 \mathrm{sec}-$ ondary boarding schools was obtained from a known population of 76 secondary boarding schools using the sample size formula of Yamane (1967) as follows:

$$
n=\frac{N}{1+N(e)^{2}}
$$


where:

$$
\begin{aligned}
& n \text { - the sample size } \\
& N \text { - the population size } \\
& e \text { - the acceptable margin of error }(0.05) .
\end{aligned}
$$

\section{Analytical framework}

To identify constraints hindering the adoption of precooked beans, descriptive statistics such as percentages and frequency distribution were used. The purpose was to rank those constraints according to their intensity to know which ones are prominent. Data was presented in tables.

To analyze factors influencing the willingness of secondary boarding schools to adopt precooked beans, a logistic regression model (Logit model) was used. Logit model was preferred over linear regression models such as Ordinary Least Squares and Linear Probability models for it is best fitted when the dependent variable is a dichotomous variable.

Logistic regression of the willingness to adopt was specified as 1 if the school is willing to adopt precooked beans, and 0 if the school is not willing to adopt precooked beans. The exogenous variables included: age of caterer, gender of caterer, education level of caterer, working experience of caterer, age of institution, type of institution, geographical location of institution, size of institution, type of market, distance to market, perceived price and perceived availability of precooked beans.

The major purpose of logistic regression was to predict the probability of a school being willing to adopt precooked beans. As such, according to Greene (2012), the functional form of logit model is written as follows:

$$
P=(Y=1)=\frac{e^{\beta X i}}{1+e^{\beta X i}}
$$

With the cumulative distribution function as follows:

$$
F(\beta x)=\frac{1}{1+e^{\beta X i}}
$$

where:

$Y$ - is the willingness to adopt precooked beans

$X i-$ are the independent variables

$\beta s$ - are the slope parameters associated with independent variables.

\section{RESULTS AND DISCUSSION}

Socioeconomic characteristics of the caterer were analyzed using percentages, means and standard deviations, and the results are presented in tables. Results indicated that the average age for caterers was 40 years and their average working experience was 10 years. The results of distribution of socioeconomic characteristics of caterers are presented in Table 1 below.

Table 1. Distribution of socioeconomic characteristics of caterers

\begin{tabular}{lclcc}
\hline \multicolumn{1}{c}{ Variable } & $\mathrm{N}$ & \multicolumn{1}{c}{ Category } & Frequency & Percent \\
\hline Age of caterer & 64 & $<30$ years & 5 & 7.8 \\
& & 30-50 years & 52 & 81.3 \\
& & $>50$ years & 7 & 10.9 \\
& 64 & male & 24 & 37.5 \\
Gender of & & female & 40 & 62.5 \\
caterer & 64 & high school & 7 & 10.9 \\
Education level & partial university & 19 & 29.7 \\
of caterer & & university & 38 & 59.4 \\
& & $<10$ years & 41 & 64.1 \\
Working experi- & 64 & 11-20 years & 21 & 32.8 \\
ence of caterer & & $>20$ years & 2 & 3.1 \\
& & &
\end{tabular}

Source: own elaboration.

The results of descriptive statistics of socioeconomic characteristics of caterers are presented Table 2 below.

Table 2. Descriptive statistics of socioeconomic characteristics of caterers

\begin{tabular}{lrrrrc}
\hline \multicolumn{1}{c}{ Variables } & N & $\begin{array}{c}\text { Mini- } \\
\text { mum }\end{array}$ & $\begin{array}{c}\text { Maxi- } \\
\text { mum }\end{array}$ & Mean & $\begin{array}{c}\text { Std. } \\
\text { deviation }\end{array}$ \\
\hline Age of caterer & 64 & 27 & 59 & 39.94 & 7.551 \\
$\begin{array}{l}\text { Working } \\
\begin{array}{l}\text { experience of } \\
\text { caterer }\end{array}\end{array}$ & 64 & 2 & 24 & 9.61 & 5.898 \\
\hline
\end{tabular}

Source: own elaboration.

Further, organizational characteristics of interviewed schools were analyzed using descriptive statistics including mean and standard deviation (where applicable), and distribution (frequency and percentages). 
Table 3. Distribution of organizational characteristics of schools surveyed

\begin{tabular}{lcccc}
\hline \multicolumn{1}{c}{ Variable } & $N$ & \multicolumn{1}{c}{ Category } & Frequency & Percent \\
\hline Age of school & 64 & $<10$ years & 10 & 15.6 \\
& & 10-24 years & 36 & 56.3 \\
& & $>24$ years & 18 & 28.1 \\
Type of school & 64 & private & 36 & 56.3 \\
& & public & 28 & 43.7 \\
Geographical & 64 & rural & 21 & 32.8 \\
location of & & urban & 43 & 67.2 \\
school & & $<500$ people & 42 & 65.6 \\
Size of school & 64 & 13 & 20.3 \\
& & 500-700 people & 9 & 14.1 \\
\hline
\end{tabular}

Source: own elaboration.
The results indicated that the average age of institutions surveyed was 22 years whereas their average size was 478 people. Table 3 below presents the distribution of organizational characteristics of the schools surveyed.

Further, the results of descriptive statistics of organizational factors influencing the willingness of secondary boarding schools to adopt precooked beans are presented in Table 4 below.

\section{Constraints impeding the adoption of precooked beans among secondary boarding schools}

The results revealed that 62 out of 64 schools have not adopted precooked beans, and 7 major constraints limiting the adoption of precooked beans in those schools were mentioned. Table 5 presents the frequency and percentage of major constraints limiting those schools from adopting precooked beans.

Lack of sufficient information about precooked beans has been identified as the main constraint which has limited the adoption of precooked beans among

Table 4. Descriptive statistics of organizational factors influencing the willingness to use precooked beans

\begin{tabular}{llccc}
\hline \multicolumn{1}{c}{ Variables } & \multicolumn{1}{c}{ Description } & Measurement & Mean & Standard deviation \\
\hline Age & Age of institution & Years & 21.97 & 15.056 \\
Size of institution & Number of people fed by the institution & Number & 477.58 & 190.237 \\
\hline
\end{tabular}

Source: own elaboration.

Table 5. Distribution of primary and secondary constraints impeding the adoption of precooked beans among secondary boarding schools

\begin{tabular}{lcc}
\hline \multicolumn{1}{c}{ Constraints } & \multicolumn{2}{c}{ Distribution } \\
\cline { 2 - 3 } & Frequency & $\%$ \\
\hline Lack of sufficient information about precooked beans & 31 & 50 \\
Unavailability of precooked beans & 21 & 32.3 \\
Perceived high price of precooked beans & 18 & 29 \\
Distrust in the sustainability claims of the precooked beans industry & 10 & 16.1 \\
Low nutritional value of precooked beans & 6 & 9.6 \\
Inconvenient packaging of precooked beans & 3 & 4.8 \\
Inadequate storage for precooked beans & 2 & 3.2 \\
\hline
\end{tabular}

Source: own elaboration. 
secondary boarding schools. According to Shiferaw et al. (2015), the key first-stage determinants of the adoption of a new product or technology are knowledge and access to information; this allows to weigh the alternatives and evaluate relative expected benefits resulting from consuming such product or technology. Table 5 above shows that the majority $(50 \%)$ of the respondents who did not adopt precooked beans indicated the lack of sufficient information as the primary constraint. The respondents argued that they could not adopt a product without sufficient knowledge about its advantages and disadvantages.

Unavailability of precooked beans is the second major factor mentioned by respondents (33.9\%) to be the barrier to their adoption of precooked beans. The problem of unavailability of precooked beans may be attributed to the fact that precooked beans are still a new product. This is why the producers may not yet be able to supply it in several markets due to limited capacity; or else the market structure of precooked beans may be ineffective.

The third major constraint limiting secondary boarding schools from adopting precooked beans, according to the results, was the perceived high price of precooked beans. As indicated by Table 5 , this constraint was cited by $29 \%$ of the respondents who have not adopted precooked beans as one of major constraints to their adoption of precooked beans. The respondents argued that precooked beans are much more expensive than dry beans and that since they are feeding a great number of people, they cannot afford to purchase them.

Distrust in the sustainability claims of the industry is the fourth constraint which has been hindering the adoption of precooked beans in secondary boarding schools. Jansson (2011) found that lack of trust in the sustainability of the product is one of the factors that lead to negative attitudes towards it. According to Table 5, 16.1\% of respondents that have not adopted precooked beans indicated their distrust in the sustainability of precooked beans industry as one of major barriers to adoption. Those respondents claimed that since the first company producing precooked beans has closed down, there is nothing to guarantee that this new company will not also close soon after they have started cooking their beans.

The low nutritional value of precooked beans, likewise, has been indicated as the fifth major constraint to their adoption in secondary boarding schools. As indicated by findings in Table 5, 9.6\% of respondents did not adopt precooked beans because they found them not as nutritious as dry beans. The respondents argued that precooked beans do not contain soup which is normally in cooked dry bean and which makes the diet complete for students. Thus, without that soup, they cannot serve precooked beans alone with starch. Also, according to their perception, packed food products are considered less nutritious than fresh food products.

The inconvenience of precooked beans packaging was also criticized as being one of the constraints that have impeded the adoption of precooked beans by the secondary boarding schools surveyed. As indicated in Table 5, 4.8\% of respondents who have not adopted precooked beans stated this to be one of the factors which limited their adoption of precooked beans. Those respondents claimed that since they cook in bulk, unpacking small packages of $400 \mathrm{~g}$ each is hard and timeconsuming, and this makes it hard to prepare them.

Moreover, inadequate storage appeared to be a barrier to the adoption of precooked beans among secondary boarding schools, although it is the least mentioned. As shown in Table 5 , only $3.2 \%$ of respondents who have not adopted precooked beans indicated the lack of adequate storage to be among their major constraints limiting their adoption of precooked beans. They affirmed that precooked beans require an improved store to ensure the shelf life of these beans, which is different from the store they have for dry beans.

\section{Factors influencing the willingness of boarding schools to adopt precooked beans}

To determine factors influencing the willingness of secondary boarding schools to adopt precooked beans, firstly a logistic regression was carried out, and then marginal effects were measured. The results are presented in Table 6 below.

The results of marginal effects indicated that five factors significantly influence the willingness of secondary boarding schools to adopt precooked beans. The education level of caterer has a positive influence on the willingness of secondary boarding schools to adopt precooked beans at a $5 \%$ significance level. According to Table 6, a high education level of the caterer increases the likelihood of the school's willingness to adopt precooked beans by $78.6 \%$.

The results of marginal effects also confirmed that the type of institution had a negative effect on the 
Table 6. Results of logistic regression and marginal effects of factors influencing the willingness to use precooked beans

\begin{tabular}{|c|c|c|c|c|c|c|}
\hline \multirow{2}{*}{ Variables } & \multicolumn{3}{|c|}{ Logistic ratio } & \multicolumn{3}{|c|}{ Marginal effects } \\
\hline & Coeff. & Std. err. & $P>Z$ & $\mathrm{Dy} / \mathrm{dx}$ & Std. err. & $P>Z$ \\
\hline Age of caterer & -0.207 & 0.165 & 0.211 & -0.058 & 0.043 & 0.170 \\
\hline Gender of caterer & -0.483 & 1.220 & 0.692 & -0.160 & 0.303 & 0.599 \\
\hline Education level of caterer & 2.719 & 1.278 & 0.033 & 0.786 & 0.337 & 0.020 \\
\hline Working experience of caterer & 0.122 & 0.214 & 0.570 & 0.042 & 0.052 & 0.427 \\
\hline Age of institution & 0.012 & 0.214 & 0.768 & 0.001 & 0.011 & 0.904 \\
\hline Type of institution & -3.722 & 1.726 & 0.031 & -0.705 & 0.220 & 0.001 \\
\hline Geographical location of institution & -4.106 & 2.093 & 0.050 & -0.810 & 0.169 & 0.000 \\
\hline Size of institution & -0.010 & 0.005 & 0.033 & -0.003 & 0.001 & 0.026 \\
\hline Type of market & -.0793 & 1.418 & 0.576 & -0.242 & 0.355 & 0.495 \\
\hline Distance to market & -0.083 & 0.202 & 0.680 & -0.048 & 0.045 & 0.283 \\
\hline Perceived high price of precooked beans & -1.107 & 0.495 & 0.005 & -0.291 & 0.131 & 0.026 \\
\hline Perceived availability of precooked beans & -9.218 & 0.699 & 0.756 & -0.025 & 0.196 & 0.900 \\
\hline Constant & 15.083 & 7.148 & 0.035 & & & \\
\hline \multicolumn{7}{|l|}{ Number of obs. $=64$} \\
\hline \multicolumn{7}{|l|}{ Prob. $>$ chi $2=0.0000$} \\
\hline Log likelihood $=-13.505$ & & & & & & \\
\hline
\end{tabular}

Source: own elaboration.

willingness of schools to adopt precooked beans. The effect was significant at $1 \%$. As shown in Table 6 above, being public makes the school less likely (by $70.5 \%$ ) to be willing to adopt precooked beans. This can be mainly due to the difference in school fees paid by students in the two types of schools. Usually, public school students pay less money, which can be a barrier to the adoption of new innovative products in such schools since those products are expected to be more expensive than old ones.

Further, the geographical location of schools was found to have a negative effect on the willingness of schools to adopt precooked beans at a $1 \%$ significance level. The results indicated that being located in rural areas makes the school less likely (by $81 \%$ ) to be willing to adopt precooked beans. This may be mainly due to the long distance from the school to precooked beans market, and also to the poor infrastructure usually present in rural areas compared to urban areas.
Furthermore, the size of institution was found to have a negative influence on the willingness of schools to adopt precooked beans at a $5 \%$ significance level. In this context, the size of institution was measured in the number of people to be fed by the school. As indicated in Table 6, a one-unit increase in the number of people to be fed by the school would reduce the likelihood of the school's willingness to adopt precooked beans by $0.3 \%$.

Lastly, the perception of secondary boarding schools about the price of precooked beans was also found to play a vital role in their willingness to adopt such beans. The results showed that the schools' perception of precooked beans price had a negative influence on their willingness to adopt those beans at a 5\% significance level. In fact, a $1 \%$ increase in the school's perception of high price of precooked beans would reduce the likelihood of the school's willingness to adopt such beans by $29.1 \%$. 


\section{CONCLUSION}

Several barriers to the adoption of precooked beans among schools were identified. The major constraint mostly mentioned was the lack of sufficient information, followed by unavailability, perceived high price, distrust in sustainability claims and low nutritional value of precooked beans. The results suggest the need for more innovations in the production of precooked beans to reduce production costs. This would reduce the price of precooked beans to an affordable level, hence it would increase the adoption rates of precooked beans. More innovations are also needed to improve the nutritious aspect of precooked beans, particularly to ensure sufficient soup content in precooked beans.

Five factors have a statistically significant effect on the willingness of schools to adopt precooked beans, namely: education level of caterer, type of institution, geographical location of the institution, size of institution and perceived price. The education level of caterer had a positive influence whereas the other four factors had a negative effect.

Further, there is need for precooked beans producers to ensure the optimal awareness of their products. To achieve this, precooked beans should be advertised in various mass media, providing sufficient information about its relative advantages over dry beans, especially the economic and environmental benefits. This would also help the producers in acquiring financial support from public and private sectors, which is necessary to fully develop the market structure for precooked beans. Consequently, the availability and accessibility of precooked beans across the country would be enhanced, and so would be the trust in sustainability of the precooked beans industry. Precooked beans producers should also consider offering precooked beans in larger packages to ensure convenience in their preparation at organizational level.

\section{SOURCE OF FINANCING}

African Economic Research Consortium

\section{ACKNOWLEDGEMENTS}

We would like to thank Egerton University for the support provided by its staff members throughout this research work. Also, our sincere gratitude goes to the
African Economic Research Consortium for sponsoring this research work.

\section{REFERENCES}

Aggarwal, P., Wilemon, D., Cha, T. (1998). Barriers to the adoption of really-new products and the role of surrogate buyers. J. Cons. Mark., 15(4), 358-371.

Akibode, S., Maredia, M. (2011). Global and regional trends in production, trade and consumption of food legume crops. Department of Agricultural, Food and Resource Economics, Michigan State University. Report submitted to SPIA, March 27, 2011.

Aseete, P., Katungi, E., Bonabana-Wabbi, J. Ugen, M. A. (2018). Consumer demand heterogeneity and valuation of value-added pulse products: a case of precooked beans in Uganda. Agric. Food Sec., 7(51), 1-13.

FAOSTAT (2012). Retrieved on $25^{\text {th }}$ September 2018 from: https://www.fao.org/faostat/en/\#country/249

FAO (2016). Pulses contribute to food security. Retrieved on $25^{\text {th }}$ September, 2018 from: www.fao.org/a-c0063e.pdf

Farmfresh (2017). Precooked beans production. Farmfresh Food Company, Kigali, Rwanda.

Greene, W. H. (2012). Econometric Analysis ( $7^{\text {th }}$ Ed). New York: MacMillan Publishing Company.

Jansson, J. (2011). Consumer Eco-Innovation Adoption: Assessing Attitudinal Factors and Perceived Product Characteristics. Bus. Strat. Env., 2(4), 57-70.

Jasiulewicz, A., Lemanowicz, M. (2016). Motives and barriers to the consumption of innovative food products by Polish and Ukrainian consumers. Rev. Inn. Comp., 2(4), 57-70.

Mudryj, A. N., Yu, N., Aukema, H. M. (2014). Nutritional and health benefits of pulses. Apply. Physiol. Nutr. Metab., 39, 1997-2014.

NISR (2014). Fourth Population and Housing Census, Rwanda, 2012. Thematic Report: Population size, structure and distribution.

Sawa, P. (2016). Pre-cooked beans could turn down heat on Africa's dwindling forests. The Thomson Reuters Foundation.

Shiferaw, B., Kebede, T., Kassie, M., Fisher, M. (2015). Market imperfections, access to information and technology adoption in Uganda: challenges of overcoming multiple constraints. Agric. Econ., 46, 475-488.

Singh, P., Singh, K. M., Shahi, B. (2016). Pulses for Sustainable Livelihood and Food Security. Munich Personal RePEc Archive, paper No. 80269.

Sirven, P., Gotanegre, J. F., Prioul, C. (1974). Geographie du Rwanda. Bruxelles: Edition A. De Boeck, Edition Rwandaise. 
Mukamugema, A., Mshenga, P. M., Birachi, A. E. (2019). Barriers to institutional adoption of new products innovation: A case of precooked beans among schools in Rwanda. J. Agribus. Rural Dev., 2(52), 139-146. http://dx.doi.org/10.17306/J.JARD.2019.01199

Van Akkeren, J., Cavaye, A. L. M. (1999). Factors Affecting Entry-Level Internet Technology Adoption by Small Business in Australia: An Empirical Study. Proc. $10^{\text {th }}$ Australasian Conference on Information Systems, 1999.

Winham, D. M., Armstrong Florian, T. L., Thompson, S. V. (2016). Low-Income US Women Under-infomed of the Specific Health Benefits of Consuming Beans. Plos ONE, 11(1), 1-12.
World Bank (2018). Rwanda - World Bank Open Data World Bank Group. Retrieved 26 ${ }^{\text {th }}$ September 2018 from: https://data.worldbank.org/country/rwanda

Yamane, T. (1967). Elementary Sampling Theory. New Jersey: Prentice Hall. 